\title{
Oats and barley toxicity in coeliac patients
}

\author{
P. G. BAKER* \\ M.B., M.R.C.P., D.C.H., D.Obst.R.C.O.G. \\ A. E. READ \\ M.D., F.R.C.P.
}

Department of Medicine, University of Bristol

\section{Summary}

The effect of addition of oats and barley to the glutenfree diets of a group of patients with coeliac disease has been studied using the oral $5 \mathrm{~g}$ xylose excretion test to assess small bowel function before and after these supplementations.

Both oats and barley were found to be potentially harmful to coeliac patients although the toxic effect of barley was more readily produced than that of oats.

On the basis of their results, the authors recommend the exclusion of both barley and oats, in addition to wheat and rye, from the coeliac diet. In view of the well recognized risk of the development of malignancy, such a diet should be followed particularly rigorously in those patients with a persistence of symptoms and of marked villous atrophy.

\section{Introduction}

From their feeding experiments in the early 1950s, Van de Kamer, Weijers and Dicke (1953b; Van de Kamer, Dicke and Weijers, 1953a) concluded that wheat, rye and oats were harmful to patients with coeliac disease, whilst other starch-containing foodstuffs, such as maize, rice and potatoes were harmless. They did not, however, investigate barley. Further investigations (Weijers and Van de Kamer, 1955) led them to incriminate the gliadin fraction of wheat gluten as the substance toxic to coeliac patients and, since then, the treatment of coeliac disease has been by means of a gluten-free diet, from which wheat and rye products are invariably removed. General agreement on the effects of other cereals in coeliac patients is, however, lacking as evidenced from the different dietary advice offered at various centres in the British Isles (Table 1).

The present study was carried out to investigate the effects of barley and oats in patients with coeliac disease so that the place of these cereals in a glutenfree diet might be more clearly defined.

The method used to assess cereal toxicity in the feeding experiments was the mean $0-5 \mathrm{hr}$ excretion of an oral $5 \mathrm{~g}$ xylose load on three occasions before and after cereal challenge. This enabled changes in excretion to be calculated directly as a percentage of

* Department of Medicine, Frenchay Hospital, Bristol BS16 1LE.
TABLE 1. Gluten-free regimes throughout the U.K. and Ireland

\begin{tabular}{lcccc}
\hline & \multicolumn{4}{c}{ Advised to exclude } \\
\cline { 2 - 5 } \multicolumn{1}{c}{ Centre } & Wheat & Rye & Barley & Oats \\
\hline Birmingham & Yes & Yes & No* & No* \\
Leicester & Yes & Yes & No* & No* \\
Cardiff & Yes & Yes & No* & No* \\
Ipswich & Yes & Yes & Yes & No \\
Leeds & Yes & Yes & No & No \\
London & & & & \\
Gt Ormond St & Yes & Yes & No* & No* \\
St Bartholomew's & Yes & Yes & Yes & Yes \\
Guy's & Yes & Yes & Yes & No \\
Wexham & Yes & Yes & No* & No* \\
Scotland & Aberdeen & & & \\
Edinburgh & Yes & Yes & No* & No* \\
Glasgow & Yes & Yes & Yes & Yes \\
Ireland & Yes & Yes & Yes $\dagger$ & Yes \\
Dublin & Yes & Yes & Yes & Yes \\
Coeliac Society & Yes & Yes & Yes & No \\
\hline
\end{tabular}

* Exclusion advised if poor response to wheat and rye exclusion.

t Allowed when patients asymptomatic, and if remain so. (Information obtained from hospital dietetics departments and the Coeliac Society.)

pre-challenge levels. In addition, it has been shown to provide a reliable index of small bowel absorption function, causes minimal discomfort and inconvenience, has no reported side effects and is simple enough for the patient to carry out the test at home (Kendall, Nutter and Hawkins, 1972). Repeat jejunal biopsies, on the other hand, are uncomfortable, very occasionally followed by intestinal bleeding or perforation, subject to marked variation within a given part of the jejunum (Thompson, 1974), and more difficult to assess quantitatively. They were, or therefore, not used at all in the present study.

\section{Methods}

Twelve patients with biopsy-proved coeliac disease completed the oats challenge diet and ten the barley diet.

All were informed volunteers who had responded to a gluten-free diet of at least 6 months' duration, their adherence to which had been carefully checked 
TABle 2. Oats

\begin{tabular}{|c|c|c|c|c|c|c|c|c|c|}
\hline \multirow[b]{2}{*}{ Patient } & \multirow[b]{2}{*}{ Age } & \multirow[b]{2}{*}{ Sex } & \multirow[b]{2}{*}{ Diet } & \multicolumn{5}{|c|}{$\%$ 0-5 hr 5 g xylose excretions } & \multirow[b]{2}{*}{ Symptoms } \\
\hline & & & & Before & diet & After & r diet & $\begin{array}{l}\text { After } \\
\text { resumption of } \\
\text { gluten-free diet }\end{array}$ & \\
\hline 1 & 54 & $\mathbf{M}$ & $\begin{array}{l}\text { Oats, } 60 \mathrm{~g} / \text { day for } \\
42 \text { days }\end{array}$ & $\left.\begin{array}{l}32 \cdot 0 \\
29 \cdot 2 \\
34 \cdot 8\end{array}\right\}$ & $32 \cdot 0$ & $\left.\begin{array}{l}16 \cdot 9 \\
13 \cdot 7 \\
14 \cdot 4\end{array}\right\}$ & $15 \cdot 0$ & $30 \cdot 1$ & Diarrhoea and flatus \\
\hline 2 & 32 & $\mathbf{F}$ & $\begin{array}{l}\text { Oats, } 60 \mathrm{~g} / \text { day for } \\
28 \text { days }\end{array}$ & $\left.\begin{array}{l}37 \cdot 4 \\
38 \cdot 4 \\
32 \cdot 3\end{array}\right\}$ & $36 \cdot 0$ & $\left.\begin{array}{l}30 \cdot 2 \\
37 \cdot 2 \\
36 \cdot 8\end{array}\right\}$ & $34 \cdot 7$ & & None \\
\hline 3 & 34 & $\mathbf{M}$ & $\begin{array}{l}\text { Oats, } 60 \mathrm{~g} / \text { day for } \\
42 \text { days }\end{array}$ & $\left.\begin{array}{l}27 \cdot 5 \\
24 \cdot 0 \\
22 \cdot 5\end{array}\right\}$ & $24 \cdot 3$ & $\left.\begin{array}{l}27 \cdot 7 \\
33 \cdot 0 \\
28 \cdot 2\end{array}\right\}$ & $29 \cdot 6$ & & $\begin{array}{l}\text { Anorexia and } \\
\text { irritability }\end{array}$ \\
\hline 4 & 42 & $\mathbf{M}$ & $\begin{array}{l}\text { Oats, } 60 \mathrm{~g} / \text { day for } \\
28 \text { days }\end{array}$ & $\left.\begin{array}{l}26 \cdot 4 \\
31 \cdot 5 \\
25 \cdot 8\end{array}\right\}$ & $27 \cdot 9$ & $\left.\begin{array}{l}26 \cdot 2 \\
31 \cdot 0 \\
30 \cdot 1\end{array}\right\}$ & $29 \cdot 1$ & & None \\
\hline 5 & 55 & $\mathbf{M}$ & $\begin{array}{l}\text { Oats, } 350 \mathrm{~g} / \text { day for } \\
14 \text { days }\end{array}$ & $\left.\begin{array}{l}28 \cdot 8 \\
28 \cdot 5 \\
30 \cdot 5\end{array}\right\}$ & $29 \cdot 6$ & $\left.\begin{array}{l}32 \cdot 5 \\
29 \cdot 6 \\
31 \cdot 0\end{array}\right\}$ & $31 \cdot 1$ & & Diarrhoea and flatus \\
\hline 6 & 43 & $\mathbf{F}$ & $\begin{array}{l}\text { Oats, } 60 \mathrm{~g} / \text { day for } \\
28 \text { days }\end{array}$ & $\left.\begin{array}{l}26 \cdot 9 \\
25 \cdot 2 \\
27 \cdot 3\end{array}\right\}$ & $26 \cdot 5$ & $\left.\begin{array}{l}18 \cdot 2 \\
22 \cdot 0 \\
20 \cdot 8\end{array}\right\}$ & $20 \cdot 3$ & & $\begin{array}{l}\text { Diarrhoea, flatus and } \\
\text { nausea }\end{array}$ \\
\hline \multirow[t]{2}{*}{7} & 59 & $\mathbf{M}$ & $\begin{array}{l}\text { Oats, } 60 \mathrm{~g} / \text { day for } \\
28 \text { days }\end{array}$ & $\left.\begin{array}{l}35 \cdot 9 \\
33 \cdot 1 \\
34 \cdot 0\end{array}\right\}$ & $34 \cdot 3$ & $\left.\begin{array}{l}22 \cdot 9 \\
24 \cdot 5 \\
21 \cdot 3\end{array}\right\}$ & $22 \cdot 9$ & $35 \cdot 0$ & $\begin{array}{l}\text { Diarrhoea, flatus and } \\
\text { nausea }\end{array}$ \\
\hline & & & $\begin{array}{l}\text { Oats, } 60 \mathrm{~g} / \text { day }+ \\
\text { avenin, } 7 \mathrm{~g} \text { for } \\
14 \text { days }\end{array}$ & $\left.\begin{array}{l}35 \cdot 6 \\
34 \cdot 8 \\
33 \cdot 9\end{array}\right\}$ & $34 \cdot 5$ & $\left.\begin{array}{l}22 \cdot 4 \\
26 \cdot 3 \\
24 \cdot 5\end{array}\right\}$ & $24 \cdot 2$ & & $\begin{array}{l}\text { Diarrhoea, flatus and } \\
\text { nausea }\end{array}$ \\
\hline 8 & 58 & $\mathbf{M}$ & $\begin{array}{l}\text { Oats, } 60 \mathrm{~g} / \text { day for } \\
100 \text { days }\end{array}$ & $\left.\begin{array}{l}16 \cdot 7 \\
17 \cdot 3 \\
14 \cdot 4\end{array}\right\}$ & $16 \cdot 0$ & $\left.\begin{array}{l}16 \cdot 8 \\
18 \cdot 0 \\
19 \cdot 5\end{array}\right\}$ & $18 \cdot 1$ & & None \\
\hline 9 & 54 & $\mathbf{M}$ & $\begin{array}{l}\text { Oats, } 60 \mathrm{~g} / \text { day for } \\
28 \text { days }\end{array}$ & $\left.\begin{array}{l}27 \cdot 1 \\
31 \cdot 9 \\
30 \cdot 0\end{array}\right\}$ & $29 \cdot 3$ & $\left.\begin{array}{l}22 \cdot 6 \\
25 \cdot 1 \\
21 \cdot 3\end{array}\right\}$ & $23 \cdot 0$ & & None \\
\hline 10 & 35 & $\mathbf{F}$ & $\begin{array}{l}\text { Oats, } 60 \mathrm{~g} / \text { day for } \\
28 \text { days }\end{array}$ & $\left.\begin{array}{l}24 \cdot 6 \\
25 \cdot 3 \\
28 \cdot 4\end{array}\right\}$ & $26 \cdot 1$ & $\left.\begin{array}{l}21 \cdot 6 \\
25 \cdot 1 \\
22 \cdot 3\end{array}\right\}$ & $23 \cdot 0$ & & None \\
\hline 11 & 5 & $\mathbf{M}$ & $\begin{array}{l}\text { Oats, } 60 \mathrm{~g} / \text { day for } \\
28 \text { days }\end{array}$ & $\left.\begin{array}{l}20 \cdot 0 \\
25 \cdot 2 \\
23 \cdot 1\end{array}\right\}$ & $22 \cdot 7$ & $\left.\begin{array}{l}24 \cdot 2 \\
25 \cdot 4 \\
24 \cdot 9\end{array}\right\}$ & $24 \cdot 8$ & & $\begin{array}{l}\text { Anorexia and } \\
\text { irritability }\end{array}$ \\
\hline 12 & 48 & $\mathbf{F}$ & $\begin{array}{l}\text { Oats, } 60 \mathrm{~g} / \text { day for } \\
28 \text { days }\end{array}$ & $\left.\begin{array}{l}28 \cdot 1 \\
29.9 \\
30.0\end{array}\right\}$ & $29 \cdot 3$ & $\left.\begin{array}{l}27 \cdot 0 \\
30.7 \\
31 \cdot 2\end{array}\right\}$ & $29 \cdot 6$ & & None \\
\hline
\end{tabular}

using a dietary questionnaire (Baker, Barry and Read, 1975).

\section{$5 \mathrm{~g}$ xylose tests}

These were carried out in the subject's home. Patients were instructed to micturate into labelled containers $2 \mathrm{hr}$ and $5 \mathrm{hr}$ after ingesting $5 \mathrm{~g}$ xylose dissolved in water. These specimens were stored at $4^{\circ} \mathrm{C}$ in an ordinary refrigerator for up to $72 \mathrm{hr}$ before analysis in the hospital biochemistry laboratory.

To ensure that alteration in xylose excretion following cereal challenge was not due to chance variations in the results, patients carried out the test on 3 separate days before the trial and on the last 3 days of the diet. The mean of the three xylose results from before and the three after the diet were calculated. Provided that results were within one standard deviation of the mean, a reduction in this value was regarded as reflecting cereal toxicity. The results from two patients which did not meet these criteria were excluded from the trial.

In patients suspected of having suffered small bowel damage from the dietary challenge, a further xylose test was performed 7-14 days after the return to a gluten-free diet to determine whether or not the reduction in xylose excretion had been corrected.

\section{Cereal preparations}

Whole barley flour, barley flakes, oat flour and oat flakes were obtained from a local health foods shop 
TABLE 3. Barley

\begin{tabular}{|c|c|c|c|c|c|c|c|c|}
\hline \multirow[b]{2}{*}{ Patient } & \multirow[b]{2}{*}{ Age } & \multirow[b]{2}{*}{ Sex } & \multirow[b]{2}{*}{ Diet } & \multicolumn{4}{|c|}{$0-5 \mathrm{hr} \% 5 \mathrm{~g}$ xylose excretion } & \multirow[b]{2}{*}{ Symptoms } \\
\hline & & & & Before diet & After & diet & $\begin{array}{l}\text { After resumption } \\
\text { of gluten-free } \\
\text { diet }\end{array}$ & \\
\hline 1 & 54 & $\mathbf{M}$ & $\begin{array}{l}\text { Barley, } 120 \mathrm{~g} / \text { day } \\
\text { for } 7 \text { days }\end{array}$ & $\left.\begin{array}{l}27 \cdot 9 \\
27 \cdot 5 \\
25 \cdot 1\end{array}\right\} 26 \cdot 8$ & $\left.\begin{array}{r}7 \cdot 4 \\
9 \cdot 3 \\
10 \cdot 0\end{array}\right\}$ & $8 \cdot 9$ & $32 \cdot 0$ & $\begin{array}{l}\text { Abdominal pain, } \\
\text { diarrhoea and flatus }\end{array}$ \\
\hline 2 & 36 & $\mathrm{~F}$ & $\begin{array}{l}\text { Barley, } 120 \mathrm{~g} / \text { day } \\
\text { for } 21 \text { days }\end{array}$ & $\left.\begin{array}{l}25 \cdot 0 \\
24 \cdot 4 \\
22 \cdot 9\end{array}\right\} 24 \cdot 1$ & $\left.\begin{array}{l}16 \cdot 1 \\
19 \cdot 7 \\
18 \cdot 1\end{array}\right\}$ & $18 \cdot 0$ & & None \\
\hline 3 & 33 & $\mathbf{F}$ & $\begin{array}{l}\text { Barley, } 120 \mathrm{~g} / \text { day } \\
\text { for } 21 \text { days }\end{array}$ & $\left.\begin{array}{l}29 \cdot 7 \\
25 \cdot 8 \\
29 \cdot 7\end{array}\right\} 28 \cdot 4$ & $\left.\begin{array}{l}28 \cdot 7 \\
34 \cdot 3 \\
30 \cdot 6\end{array}\right\}$ & $31 \cdot 2$ & & None \\
\hline 4 & 32 & $\mathrm{~F}$ & $\begin{array}{l}\text { Barley, } 120 \mathrm{~g} / \text { day } \\
\text { for } 28 \text { days }\end{array}$ & $\left.\begin{array}{l}33 \cdot 8 \\
28 \cdot 0 \\
31 \cdot 0\end{array}\right\} 30.9$ & $\left.\begin{array}{l}30 \cdot 4 \\
26 \cdot 0 \\
31 \cdot 6\end{array}\right\}$ & $29 \cdot 3$ & & None \\
\hline 5 & 34 & $\mathbf{M}$ & $\begin{array}{l}\text { Barley, } 120 \mathrm{~g} / \text { day } \\
\text { for } 28 \text { days }\end{array}$ & $\left.\begin{array}{l}30 \cdot 8 \\
32 \cdot 9 \\
27 \cdot 4\end{array}\right\} 30 \cdot 4$ & $\left.\begin{array}{l}24 \cdot 5 \\
20 \cdot 1 \\
21 \cdot 9\end{array}\right\}$ & $22 \cdot 2$ & & Diarrhoea and flatus \\
\hline 6 & 42 & $\mathbf{M}$ & $\begin{array}{l}\text { Barley, } 120 \mathrm{~g} / \text { day } \\
\text { for } 28 \text { days }\end{array}$ & $\left.\begin{array}{l}25 \cdot 4 \\
27 \cdot 2 \\
23 \cdot 2\end{array}\right\} 25 \cdot 3$ & $\left.\begin{array}{l}24 \cdot 5 \\
20 \cdot 8 \\
23 \cdot 5\end{array}\right\}$ & $22 \cdot 7$ & & None \\
\hline \multirow[t]{2}{*}{7} & 38 & $\mathbf{M}$ & $\begin{array}{l}\text { Barley, } 120 \mathrm{~g} / \text { day } \\
\text { for } 3 \text { days }\end{array}$ & $\left.\begin{array}{l}22 \cdot 7 \\
22 \cdot 8 \\
25 \cdot 1\end{array}\right\} 23 \cdot 5$ & $\left.\begin{array}{r}11 \cdot 3 \\
7 \cdot 6 \\
9 \cdot 6\end{array}\right\}$ & $9 \cdot 5$ & & $\begin{array}{l}\text { Abdominal pain, } \\
\text { flatus and diarrhoea }\end{array}$ \\
\hline & & & $\begin{array}{l}\text { Beer, } 1 \text { pint/day } \\
\text { for } 2 \text { days; } \\
0.5 \text { pint/day for } \\
12 \text { days }\end{array}$ & $\left.\begin{array}{l}25 \cdot 0 \\
26 \cdot 1\end{array}\right\} 25 \cdot 5$ & $\left.\begin{array}{l}16 \cdot 2 \\
16 \cdot 5\end{array}\right\}$ & $16 \cdot 4$ & $23 \cdot 5$ & Flatus and diarrhoea \\
\hline 8 & 55 & $\mathbf{M}$ & $\begin{array}{l}\text { Barley, } 120 \mathrm{~g} / \text { day } \\
\text { for } 28 \text { days }\end{array}$ & $\left.\begin{array}{l}32 \cdot 0 \\
27 \cdot 7 \\
26 \cdot 9\end{array}\right\} 28 \cdot 8$ & $\left.\begin{array}{l}29 \cdot 2 \\
26 \cdot 7 \\
28 \cdot 5\end{array}\right\}$ & $26 \cdot 1$ & & None \\
\hline 9 & 52 & $\mathbf{M}$ & $\begin{array}{l}\text { Barley, } 120 \mathrm{~g} / \text { day } \\
\text { for } 14 \text { days }\end{array}$ & $\left.\begin{array}{l}31 \cdot 2 \\
29 \cdot 3 \\
34 \cdot 7\end{array}\right\} 31 \cdot 7$ & $\left.\begin{array}{l}16 \cdot 1 \\
17 \cdot 4 \\
13 \cdot 7\end{array}\right\}$ & $15 \cdot 7$ & & Flatus and diarrhoea \\
\hline 10 & 59 & $\mathbf{M}$ & $\begin{array}{l}\text { Barley, } 120 \mathrm{~g} / \text { day } \\
\text { for } 6 \text { days }\end{array}$ & $\left.\begin{array}{l}34 \cdot 0 \\
35 \cdot 6 \\
35 \cdot 0\end{array}\right\} 34 \cdot 9$ & $\left.\begin{array}{l}4 \cdot 0 \\
2 \cdot 1 \\
2 \cdot 9\end{array}\right\}$ & $3 \cdot 0$ & $31 \cdot 8$ & $\begin{array}{l}\text { Flatus, diarrhoea and } \\
\text { abdominal pain }\end{array}$ \\
\hline \multirow[b]{2}{*}{ Patient } & & & & \multicolumn{4}{|c|}{$0-5 \mathrm{hr} \% 5 \mathrm{~g}$ xylose excretion } & \\
\hline & Age & Sex & Diet & Before diet & After & diet & $\begin{array}{l}\quad \text { After } \\
\text { resumption of } \\
\text { gluten-free diet }\end{array}$ & Symptoms \\
\hline 1 & 32 & $\mathbf{F}$ & $\begin{array}{l}\text { Gluten, } 20 \mathrm{~g} \\
\text { single dose }\end{array}$ & $31 \cdot 2$ & $33 \cdot 0$ & & & None \\
\hline 2 & 5 & $\mathbf{M}$ & $\begin{array}{l}\text { 'Weetabix', 2/day } \\
\text { for } 4 \text { days } \\
\text { (=gluten, approx. } \\
4 \text { g/day) }\end{array}$ & $24 \cdot 8$ & $1 \cdot 5$ & & & $\begin{array}{l}\text { Diarrhoea, flatus, } \\
\text { nausea and abdominal } \\
\text { pain }\end{array}$ \\
\hline
\end{tabular}

able to obtain them in an uncontaminated and pure form from reputable suppliers. Gluten was obtained from British Drug Houses. Avenin, being unavailable commercially, was prepared from oatflakes using the method of Van de Kamer et al. for preparing gluten from wheatflour (1953). These cereals were incorporated into the diet in the form of breakfast cereals, bread, cakes, biscuits and soup or gravy thickeners whilst the avénin was taken dissolved in orange juice.

Patients were instructed to take the cereal in a specified daily amount for up to 4 weeks, unless 70 definite adverse effects occurred, at which time the $\overline{0}$ xylose tests were repeated and cereal ingestion 
stopped. Any untoward symptoms were recorded by the patients.

\section{Results \\ Oats}

Three of the twelve patients (nos 1, 6 and 7) challenged with oats developed gastrointestinal symptoms which remitted within $72 \mathrm{hr}$ of their return to a gluten-free diet and a mean reduction in xylose excretion to between $47 \%$ and $77 \%$ of the pre-challenge levels. Two of these patients carried out a further xylose test about one week after the disappearance of symptoms. This showed a return to pre-challenge levels. One patient also agreed to be rechallenged with an increased dose of oats, achieved by the use of avenin in addition to oatflakes and oatflour, and again developed gastrointestinal symptoms with an impairment of xylose excretion.

Of the nine patients who had no alteration in xylose excretion, six remained completely asymptomatic but the remainder (nos 3,5 and 11) complained of some anorexia and irritability towards the end of the diet.

\section{Barley}

Six of the patients (nos 1, 2, 5, 7, 9 and 10) challenged with barley developed gastrointestinal upset and an impairment of xylose excretion to between $9 \%$ and $75 \%$ of mean pre-challenge level. One patient (no. 7) was also adversely affected by beer which produced a $30 \%$ reduction in xylose excretion in a dose of $560 \mathrm{ml} /$ day for 2 days and $280 \mathrm{ml} /$ day for a further 12 days.

In all six patients, bowel function returned to normal and symptoms abated within $72 \mathrm{hr}$ of stoping barley ingestion. Patients nos 1,7 and 10 also carried out xylose tests about 10 days after returning to their gluten-free diets; these results were comparable to those obtained before cereal challenge.

The four patients in whom no reduction in xylose excretion was detected remained asymptomatic throughout the barley trial.

\section{Discussion}

Since the gliadins of both wheat and rye, which belong to the Gramineae family of plants, are known to be harmful to coeliac patients, the question arises as to whether the equivalent proteins, known as prolamines, in other members of the group are also toxic. For barley, this is termed hordein and for oats avenin. It should be noted that, whereas barley contains about the same amount of prolamine as do wheat and rye, oats has only a quarter of this amount. Rice, incidentally, has one thirtieth (which may be a reason for its lack of toxicity in coeliac patients (Brohult and Sandegren, 1954). Various workers have investigated the effects of these other cereals in coeliac patients but their results are conflicting or inconclusive.

Reports suggesting that barley is toxic have come from Rubin et al. (1962), who found histological evidence of mucosal damage following direct instillation of a barley flour slurry into the ileum of two coeliac patients, and Hansted (1956), who noted an increased faecal fat excretion in some of a group of coeliac children challenged with barley. There are, however, no publications relating to the effects of beer in patients with coeliac disease. This is the main barley product consumed in the U.K., barley bread being eaten mostly in parts of Scotland only. Approximately $500 \mathrm{~g}$ barley are used in the production of one litre of beer (personal communication, Chief Chemist, Courage Western Ltd) and the amino acids present are those also found in hordein.

The effects of oats in coeliac patients have received more attention than barley. It is mainly eaten in the form of porridge, especially in Scotland where a daily intake of 50-60 g oats is commonly consumed in this way.

Van de Kamer and his colleagues in 1953 were the first workers to investigate oats toxicity in patients with coeliac disease and found that it could be harmful (Van de Kamer et al., 1953a). Further work by Van de Kamer, Weijers and Wauters (1970) supported this view. Oats toxicity has, however, been denied by other workers (Hansted, 1956; Sheldon, 1955; Moulton, 1958; Dissanayake, Truelove and Whitehead, 1974).

The variability in susceptibility to gluten of patients with coeliac disease is well recognized, relapse at the clinical, morphological or biochemical level following reintroduction of gluten occurring any time between a few days and several years later (Visakorpi and Savilahti, 1970; Schmerling and Shiner, 1970; Hamilton and McNeill, 1972; Rubin et al., 1962).

The results shown in the two coeliac patients challenged with gluten can be seen to underline this variability in gluten susceptibility and provide a basis for the interpretation of the results with varley and oats. Six of ten patients challenged with barley, four of twelve challenged with oats and one challenged with beer developed toxic effects. Assuming that coeliac patients may also vary in their susceptibility to hordein or avenin, these results indicate that barley (including its consumption as beer) and oats can produce harmful effects in coeliac patients. Weight for weight, barley flour was found to be more toxic than oats flour. This may be related to the much lower content of avenin in oats than hordein in barley. The well recognized failure of many coeliac patients to achieve a normal mucosal histology despite prolonged gluten restriction may, therefore, 
be related to continued ingestion of oats or barley products.

It is therefore suggested that oats and barley in addition to wheat and rye be excluded from the diet of coeliac patients and that this regime should be enforced with particular rigour in patients who have not satisfactorily benefited from prolonged gluten withdrawal.

\section{References}

BAKer, P.G., BARRY, R.E. \& READ, A.E. (1975) Detection of continuing gluten ingestion in treated coeliac patients. British Medical Journal, 1, 486.

Brohult, S. \& SANDEgren, E. (1954) Protein structure. In: The Proteins (Ed. by H. Neurath and K. Bailey), Vol. 2 (A), p. 487. New York, Academic Press.

Dissanayake, A.S., Truelove, S.C. \& Whitehead, R. (1974) Lack of harmful effect of oats on small intestinal mucosa in coeliac disease. British Medical Journal, 4, 189.

Hamilton, J.R. \& MCNeILl, M. (1972) Childhood celiac disease: response of treated patients to a small uniform daily dose of wheat gluten. Journal of Pediatrics, 81, 885.

HANSTED, C. (1956) Effects of cereals in celiac disease. 8th International Congress of Pediatrics Exhibition, 137. Copenhagen.

Kendall, M.J., NutTer, S. \& Hawkins, C.S. (1972) Testing gluten sensitivity by the xylose test. Lancet, ii, 667 .

Moulton, A.C.L. (1958) The place of oats in the coeliac diet. Archives of Disease in Childhood, 34, 51.

Rubin, C.E., Brandborg, L.L., Flick, A.L., MacDonald, W.C., Parkins, R.A., Parmentier, C.M., Phelps, P.,
SRIBhibHAH, S. \& TRIER, J.S. (1962) Biopsy studies on the pathogenesis of coeliac sprue. In: Intestinal Biopsy, p. 67.2 Ciba Foundation Study Group No. 14. Ciba Drug Co.

Schmerling, D.H. \& SHINer, M. (1970) The response of the $C$. intestinal mucosa to the intraduodenal instillation of gluten in patients with coeliac disease during remission. In: $\vec{\sim}$ Coeliac Disease (Ed. by C. C. Booth and R. H. Dowling), pp. 224-31. Edinburgh, Churchill Livingstone.

SEGAL, E. (1974) Oats toxicity in coeliac disease. British $\frac{\bar{\sigma}}{\bar{\omega}}$ Medical Journal, 4, 589.

SheldoN, W. (1955) Coeliac disease (in regard to gluten $\overparen{\Phi}$ intolerance). Lancet, ii, 1097.

Thompson, H. (1974) The small intestine at autopsy. In:œ Clinics in Gastroenterology, Vol. 3 (1), pp. 171-82. Saunders. London.

VAN DE KAMER, J.H., Dicke, W.K. \& WeIJers, H.A. (1953a) $\overrightarrow{\vec{\omega}}$ Presence in wheat of a factor having a deleterious effect in cases of coeliac disease. Acta paediatrica, 42, 34.

VAN DE KAMER, J.H., WeIJers, H.A. \& DiCKE, W.K. (1953b)윽 Investigation into the injurious constituents of wheat in 3 . connection with their action on patients with coeliac of disease. Acta paediatrica, 42, 223.

VAN DE KAMER, J.H., WeiJers, H.A. \& WAUTERS, E.A.K. (1970) Some biochemical aspects of coeliac disease: past, $-\mathcal{V}$ present and future. In: Coeliac Disease (Ed. by C. C. Booth N and R. H. Dowling), pp. 106-13. Edinburgh, Churchill $\oplus$ Livingstone.

VISAKORPI, J.K. \& SAVILAHTI, E. (1970) A clinical and morphological study of the permanence of gluten intolerance. $\vec{Z}$ In: Coeliac Disease (Ed. by C. C. Booth and R. H. Dowl-s ing), pp. 224-31. Edinburgh, Churchill Livingstone.

WeIJERS, H.A. \& VAN DE KAMER, J.H. (1955) Experiments $\vec{\bullet}$ on cause of harmful effect of wheat gliadin. Acta paedistrica, 44, 465. 